Case for Teaching

\title{
São Felipe Hospital: Capacity Management Challenge in a Hospital Emergency
}

\section{Hospital São Felipe: Desafio da Gestão da Capacidade em uma Emergência} Hospitalar

\author{
Claudia Affonso Silva Araujo, 10 \\ Kleber Fossatti Figueiredo ${ }^{10}$
}

\section{INTRODUCTION}

Dr. Fabio Antunes left the tense board meeting aware that his job was on the line. Since he had taken on the position of Emergency Director at Hospital São Felipe over a year ago, his challenges had only grown: increasing number of outpatients coming for emergency treatment, many complaints from customers about having to wait a long time, patients expressing their disgust at so many delays in the waiting room, etc.

That morning in July 2017, the board had met to discuss the results of the satisfaction survey carried out with the hospital's customers. The emergency results were disappointing and most of the complaints were associated with the waiting conditions. Fabio was given a 20-day deadline to present an action plan to resolve the problems in emergency care. The meeting was closed with the following words from the Hospital's Managing Director, Dr. Alberto Franco:

"The culprits are present in this room. This is not the level of services I want to give to customers coming to us for emergency care. I want immediate action. This situation is tainting our image and is unacceptable. I want an action plan to be presented to me within 20 days that will reverse this situation. We will talk again on Monday, August 7.”

\begin{tabular}{|c|c|c|c|c|c|c|c|c|c|}
\hline & 1 & 2 & 3 & 4 & 5 & 6 & 7 & 8 & 9 \\
\hline $1^{\text {st }}$ round & (x) & $\stackrel{\phi}{2}$ & $\stackrel{0}{2}$ & & & & & & \\
\hline $2^{\text {nd }}$ round & $\underline{8}$ & 8 & & & & & & & \\
\hline
\end{tabular}




\section{BACKGROUND}

Hospital São Felipe (HSF) is a traditional hospital in Minas Gerais founded in 1940 that operates as a private, open-capital hospital that in 2017 had 180 beds, a staff of approximately 500 nursing professionals, an open clinical body, providing health services to private and insured patients of classes A, B, and C. The hospital was a dream come true of two young doctors who had been friends since college and wanted to build a hospital "of excellence, recognized for the quality of the services provided," as they used to say.

In 2017, the hospital was in the second generation being administered by the sons of the founders: two doctors and one economist. The big concern was succession since the third generation was not interested in the hospital and talked about selling the institution. The lack of interest by the third generation could be explained in part due to the challenges faced by the hospital in the last twenty years, which had generated a great deal of instability for the families of the founders. The hospital had been facing financial difficulties since the 1990s due to the increasing costs of the sector and the drop in the number of elective procedures in the institution. With the increase in costs, the hospital started to save on material and personnel, generating dissatisfaction in its clinical and nursing staff, who became overloaded, and this dissatisfaction was reflected in patient care and with the physicians who performed their surgeries there.

Doctors and patients dissatisfied with the quality of the services, staff and health professionals succumbing to lack of motivation, and long lines for emergency care characterized the last 20 years of HSF. As if this were not enough, the situation worsened in 2016 with a fight between the Director of Operations and the Medical Director, sons of the founders, because of the difference in opinion about the direction the hospital should take to regain its reputation as a hospital of excellence. This fight resulted in hiring Alberto Franco, a critical care physician experienced in hospital management, to take over the hospital's General Administration in February 2017 with the main challenge of recovering HSF's reputation with its customers as a hospital of excellence.

In 2016, the hospital's emergency unit received an average of about 6,300 patients per month (Table A1) divided into three specialties: general clinic, orthopedics, and ophthalmology. General clinic was responsible for the highest volume of care $(75 \%)$ followed by orthopedics $(15 \%)$ and ophthalmology (10\%). Between January 2016 and February 2017, the emergency unit received approximately 87,000 patients along with a total of 617 written complaints. Although it seems like a small number, the hospital managers knew that few were the customers that complained formally and that most went away talking badly about the institution. Moreover, the low levels of satisfaction left it clear that the problem was serious.

\section{EMERGENCY CARE STRUCTURE AND PROCESS}

The São Felipe emergency unit was located on the ground floor of the hospital building with an area of about $250 \mathrm{~m}^{2}$ divided up as follows: three desk positions, two of which are for receiving patients (filling out forms, checking data, etc.), and the third to request authorization of examinations from the health insurance companies; five small doctor offices; ten box beds; and a team of seven physicians, five general practitioners, one orthopedist, and one ophthalmologist. Of the five general practitioners, two provided care for the patients in the boxes, another two were calling the patients who were waiting for care, and one was the shift supervisor dividing his time between internal activities and patient care. The orthopedist and ophthalmologist provided their care in their specialty.

The doctors worked 12-hour shifts with the change taking place at $7 \mathrm{AM}$ and 7 PM. After 7 PM there were only four general practitioners (two attending to the line, calling the patients), one orthopedist, and one ophthalmologist.

During the day, the emergency unit had a team of two nurses and five nurse technicians whose days off were not covered. During the night shift, the team was one nurse with someone covering on days off and five technicians without anyone covering them on their days off. The nursing staff had one day off a week, so every week there were two day shifts with one less nurse and five shifts with one less technician.

When patients arrived at the emergency room, they were given a number and had to wait in the reception room to be called by one of the two receptionists to fill out the patient care form. At that point, they were assigned to one of the emergency unit's three specialties. After filling out the form, which took about 5 minutes, the patient had to wait to be called for screening, which was done by a nurse in a space prepared for this purpose, and was classified as red (severe, $3 \%$ of the cases), yellow (medium, $7 \%$ of the cases), or green (not severe, $90 \%$ of the cases). Severe cases were referred directly to the emergency unit's internal area for hospitalization, but the cases of medium and low severity returned to the waiting room to wait to be called for medical care. Screening had been initiated in the hospital in January 2017 and was performed only in 
the period from 7 AM to 7 PM. Fabio advocated screening 24 hours a day, but had not yet gotten support from the managers.

Since waiting to be screened could take up to an hour, most patients, when physicians were available, went directly to medical care without going through that stage. The doctors themselves took the initiative to go to the waiting room and call the next patient of their specialty. Those who went through screening often had a negative impression of the process and saw it as a stall tactic and an unnecessary step.

After screening, when this occurred, patients returned to the same room to wait for the doctor to call them to come into one of the five offices. This wait on busy days could take more than 2 hours. The patients were called by an electronic panel where their number would appear. As the screening and/or medical care usually took a long time, about $5 \%$ of the patients gave up and would go away before receiving any care.

The request for laboratory tests or for some X-ray was common and occurred in approximately $52 \%$ of the visits. When an exam was requested, patients were sent back to the same room where they had previously been waiting for the exam to be authorized and later performed. This stage could take hours depending on the health insurance company. After the exam was done, the patient was again sent back to the same room to wait for the result. The result of a blood test, for example, used to take about 2 hours to be ready.

\section{THE LINE IN THE EMERGENCY UNIT}

Fabio left the meeting ready to meet the Managing Director's request and his first step was to gather the information needed to develop the action plan and mitigate the waiting problem in the hospital's emergency unit. He got his team together and asked them to send him all the documents/information available about the unit's capacity and demand. Fabio knew that the first step was to understand demand behavior, analyze the process capacity, and identify bottlenecks.

In less than 24 hours, emails kept coming in with files containing relevant information such as patient arrival rate per specialty, per day of the week, per hour of the day, per insurance company, etc. Fabio was overwhelmed with so much information.

Due to the complexity of the situation and the diversity of cases received and exams requested, Fabio thought it would be better to focus his efforts on the process from when the patients arrived until they would see a doctor. The procedure for carrying out exams would be checked at another time. He also reached the conclusion that the focus of attention should be on general clinic care since the number of patients was much higher. According to his experience, there were no long waits for the other two specialties. He then studied the waiting times in the stages of the process since when patients arrived until they were treated by the general practitioner. But how could those times be recorded? The hospital did not have those records.

Fabio chose to assign two interns to accompany patients arriving at the hospital and jot down all the times along the process: what time they arrived, how long they waited to fill out the form at the reception desk, how long it took to locate their records, how long they waited to be screened, the screening time, and so on. During two weeks (Monday through Friday), the two interns spent the day in the emergency unit (from $9 \mathrm{AM}$ to $7 \mathrm{PM}$ ) and were able to follow the times of 151 patients. The information collected is summarized in Table A2. They also noted that $67 \%$ of these patients did not go through screening and were treated directly by the physician.

Another factor Fabio noticed was the wide variance in demand throughout the week and during different hours of the day. Monday was usually a critical day and on any day of the week the movement began to increase beginning at $10 \mathrm{AM}$. The behavior of the demand during the days of the week and throughout the hours of the day in April 2017 is shown in Tables A3 and A4.

When analyzing the data in Tables A3 and A4, Fabio observed that $88.5 \%$ of the patients arrived at the hospital between $8 \mathrm{AM}$ and $10 \mathrm{PM}$ and that the critical day was really Monday.

Once all this information was gathered, Fabio studied where to begin. Would this information be enough? What other data should he study? His time was short. At the age of 35 , he had not expected that as a doctor one day he would face a challenge like this one that could cost him his job. This left him paralyzed.

Still lost in his thoughts with so many uncertainties, Fabio was interrupted by his secretary who handed him a manila envelope addressed to "Head of the Emergency Unit at Hospital São Felipe”. 
"Rio de Janeiro, July 3, 2017

Dear Dr. Fabio,

On Sunday, June 25, I had the misfortune to need to use the emergency care unit at São Felipe. It was a very bad experience. I was feeling poorly with a lot of pain in my back and my wife ran me to the hospital where we arrived around 11 o'clock in the morning. At the reception desk, after all the bureaucracy, they told us to wait to be called by the electronic panel. After more than 40 minutes of waiting in a cold room - the air conditioning was on maximum cold - my wife went to talk to one of the receptionists who in a dry tone replied, "Everyone is in the same boat, so you have to wait." At this point, my pain was unbearable and I could barely breathe. Beyond the cold, a creaking door was making me go mad. At my side was a lady in her 80 s with chest pains who was waiting standing up because the waiting room was crowded, but there were several caretakers also sitting down who made no qualms about not giving up their seat for her. Even though I did not feel much better than her, I decided to offer my seat to the elderly lady and went to complain with the receptionists, who always answered me with arrogance to wait. I told them that this was inhumane and that there were people really sick there and were not being helped, but to no avail. I felt like I was talking to robots. What kind of people did you hire? What training have they received? When I looked at the electronic panels, I noticed that their timing were not the same. We had been waiting for more than an hour and no one knew how much longer we would have to wait. What is your criterion? I saw apparently less sick people going in before others who were sicker. Why? Are they private paying patients?? What about the elderly, don't they have priority? This is disgusting!

After exactly 1 hour and 40 minutes of waiting, I was called. You can imagine my surprise when who received me was a nurse who asked me how I felt, took my pressure, and then asked me to go back to where I had already been to wait for the doctor's call. I didn't understand what was going on. When I returned to the waiting room, I could see some doctors outside the emergency unit smoking and talking on their cell phones. Completely absurd and a disregard for human life. To make the story short, after almost 3 hours of waiting, I was finally called by a doctor who asked me for blood and urine tests and a tomography scan and sent me to one of the emergency boxes. Once I got there, a girl came to ask me if I was able to provide a urine sample. I said I couldn't, so she turned to my wife and said, "So go over there to the water fountain and get some water for him so he can do the urine exam." Somewhat apprehensive, my wife went to make sure with the doctor, who was in the hallway, if she really should give me water, and the doctor reacted, "No! Only after the tomography." Shortly after, the same girl returned, who by this time we already knew was a nurse technician, and asked if I had drunk some water. My wife explained that she was oriented to wait a while. "Who said that?" asked the girl. When she was informed that it was the doctor, she left grumbling loudly, "But didn't you say to fill his bladder?" After all, what language do you speak?? If you guys can't understand each other, how much more so the patients?

The urine sample was finally collected at 4 PM and the container placed on top of a counter. No tomography... When we asked why it was taking so long, they said that they were trying to get authorization from the health insurance company. Crazy! I pay my bill every month and when I need its services, this is what I get? At 5 PM, I was sent to the tomography room and I had to walk by my urine sample that remained in the same place, absolutely 'invisible' to the emergency professionals who were more interested in telling jokes and chatting. I warned them that my urine was going to 'spoil' because it had been there for more than an hour. Once again, indifference.

Finally, after this entire terrible ordeal, it was confirmed by tomography that I was having a renal crisis. The doctor came to give me the result of the exam and said, "Don't drink water! If you tell people out there that you are having a renal crisis, they are going to tell you to drink water, but don't! If you do, you are going to end up in the hospital again!" And that was it. But what about the blood test? It would take at least 2 hours, as I was told, to get the results. And the urine test? Believe me: my urine sample was still in exactly the same place!! By this time, it was already 7 o'clock in the evening and there was a shift change. Another doctor came to visit me who told me that for a renal crisis "water is also medicine!" and that I should drink A LOT of water. Total insanity!

I left this place of madness, leaving behind my poor abandoned urine sample, a blood test without a result and without knowing whether to drink water or not.

If this is what you call health care, emergency care, I am sorry for all of us poor citizens who need your services.

Before I left, I made it a point to find out who was the head of that chaos.

\section{Worst Regards, \\ Jorge da Silva Fernandes".}

The contents of the letter were like a punch in Fabio's stomach. He picked up the phone to request that the hospital Ombudsman come to his room and for her to bring other patient reports. Within a few minutes, Ana arrived in Fabio's office with a stack of papers. They were complaints placed by patients or their relatives in the suggestion box that is located at the emergency desk. Fabio separated some reports that caught his attention the most and read them carefully. He was perplexed... He had 20 days to solve a problem that was far more serious than he had imagined. There would certainly be days of little sleep. Figure A1 provides a set of customer complaints. 


\section{ANNEX A.}

Table A1. Number of patients treated every month by emergency in the years 2015 and 2016.

\begin{tabular}{lll}
\hline Month & Year 2015 & Year 2016 \\
\hline Month & Number of patients treated & Number of patients treated \\
\hline January & 5,261 & 6,609 \\
February & 5,376 & 5,965 \\
March & 5,864 & 6,847 \\
April & 5,921 & 7,381 \\
May & 5,977 & 6,254 \\
June & 5,443 & 5,140 \\
July & 5,461 & 6,105 \\
August & 5,383 & 6,233 \\
September & 5,245 & 6,029 \\
October & 5,474 & 6,431 \\
November & 5,268 & 5,843 \\
December & 6,001 & 6,600 \\
Total & 66,674 & 75,437 \\
Monthly average & 5,556 & 6,286 \\
\hline
\end{tabular}

Note. Source: prepared by the authors.

Table A2. Times for each stage of the process from patient arrival to emergency unit until medical care: average, maximum, and minimum.

\begin{tabular}{llllllll}
\hline $\begin{array}{l}\text { Times } \\
\text { (in h:min) }\end{array}$ & $\begin{array}{l}\text { From taking } \\
\text { a number to } \\
\text { starting to fill } \\
\text { out form }\end{array}$ & Filling out form & $\begin{array}{l}\text { Waiting for } \\
\text { screening }\end{array}$ & In screening & $\begin{array}{l}\text { Waiting for } \\
\text { medical care } \\
\text { (after screening) }\end{array}$ & $\begin{array}{l}\text { Waiting for } \\
\text { medical care } \\
\text { (W/O screening) }\end{array}$ & $\begin{array}{l}\text { Receiving care } \\
\text { by the doctor }\end{array}$ \\
\hline Average & $00: 15$ & $00: 04$ & $00: 25$ & $00: 05$ & $00: 23$ & $00: 39$ & $00: 08$ \\
Maximum & $01: 05$ & $00: 21$ & $01: 35$ & $00: 12$ & $01: 18$ & $03: 01$ & $00: 23$ \\
Minimum & $00: 00$ & $00: 01$ & $00: 01$ & $00: 01$ & $00: 00$ & $00: 04$ & $00: 02$ \\
\hline
\end{tabular}

Note. Source: prepared by the authors.

Table A3. Total demand during the days of the week and throughout the hours of the day in April 2017.

\begin{tabular}{|c|c|}
\hline Day of week & Number of patients \\
\hline Sunday & 1,031 \\
\hline Monday & 1,311 \\
\hline Tuesday & 1,045 \\
\hline Wednesday & 656 \\
\hline Thursday & 725 \\
\hline Friday & 783 \\
\hline Saturday & 980 \\
\hline Total & 6,531 \\
\hline Average & 933 \\
\hline Maximum & 1,311 \\
\hline Minimum & 656 \\
\hline
\end{tabular}


Table A4. Total demand over the hours of the day.

\begin{tabular}{ll}
\hline Time of day & Number of patients arrived \\
\hline Midnight & 111 \\
1 AM & 67 \\
2 AM & 44 \\
3 AM & 43 \\
4 AM & 16 \\
5 AM & 32 \\
6 AM & 80 \\
7 AM & 167 \\
8 AM & 286 \\
9 AM & 447 \\
10 AM & 489 \\
11 AM & 513 \\
12 noon & 447 \\
1 PM & 412 \\
2 PM & 436 \\
3 PM & 424 \\
4 PM & 418 \\
5 PM & 382 \\
6 PM & 388 \\
7 PM & 400 \\
8 PM & 394 \\
10 PM & 302 \\
11 PM & 258 \\
\hline
\end{tabular}

Note. Source: prepared by the authors. Aggregate values for the 30 days of April 2017. The table shows, for example, that between midnight and 1 AM during all the 30 days in April that a total of 111 patients were treated. It also shows that the most critical time slot in terms of people arriving was 11 o'clock in the morning.

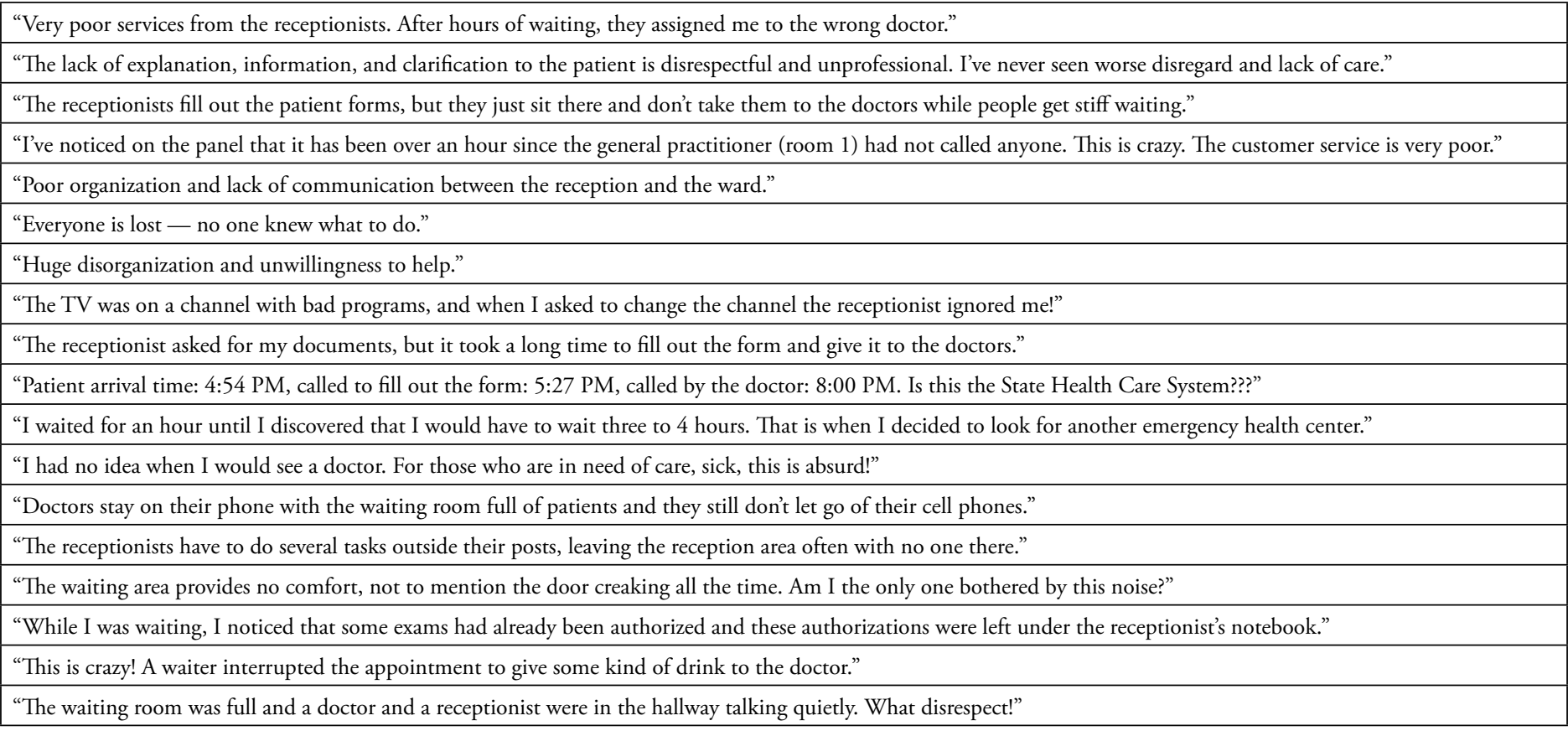

Figure A1. Reports from patients to the Ombudsman's Office. 


\section{ABSTRACT}

In July 2017, the board of directors of Hospital São Felipe, a traditional hospital located in Minas Gerais, met to discuss the results of the satisfaction survey conducted at the hospital, where it was clear there was great customer dissatisfaction with the emergency service. In the previous year, the hospital emergency service received, on average, about 6,300 patients a month, divided in three specialties: general clinic, orthopedics, and ophthalmology. The director of emergency services had twenty days to submit a plan of action to address the problems identified in the emergency area, particularly those related to the waiting lines: wait time, lack of comfort, inattention of employees, and so on. The first action taken by the director was to collect data that would enable him to analyze wait times during the process: What time did the patient arrive at the emergency service? How long the patient waited to be attended by the receptionist? How long the patient waited for triage? and so on. With these data, he believed that he would have a better understanding of the process flow and would be able to propose solutions to the problem of waiting lines in the emergency area. The case was written with the educational goal of working with the concept of capacity management in services and with ways to deal with the demand variability, especially in high-touch and unpredictable services, as in the case of an emergency service.

Keywords: waiting lines; emergency; hospital; capacity management; demand management.

\section{Educational objectives}

The Hospital São Felipe case was written based on fictitious data collected in consulting firms carried out by the authors with the pedagogical objective of working in the classroom on the concept of capacity management in services such as dealing with variability in the arrival of patients, especially in high-contact services where it is difficult to predict each patient's demands, as is the case of hospital emergency.

\section{Disciplines where the case can be used}

The case can be scheduled in disciplines, preferably graduate study level, dedicated to the topics of Service Management and Services Operations.

Although the case focuses on the discussion of hospital emergency, it was written to be discussed in courses of service management in general since the challenges of capacity and demand management in the health sector make it possible to discuss in depth the applicability of concepts in various types of services, which likewise face a high cost of lack of capacity, high variability of demand behavior, difficulty finding substitute products/ services for the moments of idleness and for specialized

\section{RESUMO}

Em julho de 2017, a diretoria do Hospital São Felipe, tradicional estabelecimento privado localizado em Minas Gerais, se reuniu para discutir os resultados da pesquisa de satisfação realizada no hospital, em que ficou clara a grande insatisfaçáo dos clientes com o atendimento da emergência. No ano anterior, a emergência do hospital atendera, em média, a cerca de 6.300 pacientes/mês, divididos nas três especialidades: clínica médica, ortopedia e oftalmologia. Ao diretor da emergência foi dado um prazo de 20 dias para apresentar um plano de açáo para resolver os problemas identificados em sua área, particularmente os relacionados à espera. A primeira atitude tomada pelo diretor da emergência foi coletar dados que viabilizassem analisar os tempos de espera ao longo do processo. De posse dos dados, ele acreditava que teria uma melhor compreensão do fluxo do processo e que seria capaz de propor soluçóes para o problema da espera na emergência. $O$ caso foi escrito, com dados fictícios, com o objetivo pedagógico de trabalhar em sala de aula o conceito de gestão de capacidade em serviços e meios de lidar com a variabilidade do processo e da demanda, como é o caso de uma emergência hospitalar.

Palavras-chave: fila de espera; emergência; hospital; gestão da capacidade; gestão da demanda.

labor force, making it difficult to relocate capacity to the activities that represent the process' bottleneck.

\section{Preparatory questions}

The discussion of the case in the classroom can be guided by the following preparatory questions:

a. Is the information submitted to Fabio Antunes enough to improve the management of the hospital's emergency process? What other information would you request?

b. With the information provided in the case, make an analysis of the flow of the emergency care process at Hospital São Felipe. Where are the bottlenecks?

c. Develop an action plan addressing aspects related to capacity management, demand management, and dealing with waiting lines. Is the lack of doctors/nurses or reception staff the main cause of customer dissatisfaction? Explain your answer.

These questions should be sent to students at least one week in advance together with the teaching case so that they can prepare before the class. 


\section{Suggested teaching approach}

This is a case in which there are management decisions to be made, encouraging students to reflect on the problem of capacity management and demand in services. There are at least three concepts that students need to know and understand to be able to make recommendations on the measures that Fabio Antunes should adopt:

1. Capacity Management (analysis of the process flow and capacity at each stage of the process);

2. Demand Management (demand behavior and variabilities introduced by the customer in the service delivery process);

3. Dealing with waiting lines (managing the waittime perception to make it less stressful for the customer).

Understanding the above concepts along with the information provided in the case will provide enough grounds for students to discuss the next steps to be taken by the hospital to improve hospital emergency management and patient experience. Thus, the following articles should be delivered in advance to the students together with the case and discussion questions, which need to be read before the individual resolution of the case: Figueiredo and Escobar (2004), Frei (2006) and Maister (1985). moments:

The approach for guiding the session involves three

1. Opening (suggested time: 45 minutes) — The teacher will open the class by encouraging students to discuss the texts on capacity and demand management assigned as prior reading. In this discussion, the teacher can stimulate the class by presenting some of the following questions:

a. The text "Capacity Management in Services" (Figueiredo \& Escobar, 2004) provides a series of mechanisms that can be used in service companies to manage capacity and demand. Which one caught your attention the most? Do you have examples to give about applying any of these mechanisms by service companies? Are these mechanisms applicable in the health sector? Why? What are the specificities of capacity and demand management in health services? Give examples from other service sectors that face challenges similar to those faced by health services.

b. Is it possible to overcome the trade-off between efficiency and quality of services? What comments do you have to make about Francis Frei's article (Frei, 2006)?

c. Any comments regarding the text "The Psychology of Waiting Lines" (Maister, 1985)? Considering the specifics about waiting in line in a hospital emergency unit, do you believe that it is possible to apply the principles proposed by Maister?

2. Small group discussion (suggested time: 45 minutes) - After introducing the theme and the concepts at the opening of the class, students should be divided into small groups (maximum of 5) to discuss the case, answering the preparatory questions proposed as a group.

3. Joint discussion (suggested time: 60 minutes) - The teacher guides the class for an in-depth analysis of each one of the questions proposed, as follows:

a. Discuss the mapping of the process made by the students in small groups and the analysis of the times for each step in comparison with the size of the team available to carry out the tasks (capacity analysis vs. demand);

b. Discuss the action plan developed by the students while reflecting on issues such as the applicability of the demand management mechanisms considering the behavior of the demand and the specificity of the services of a hospital emergency unit, such as educating/informing customers, distributing demand according to periods, appointment system, etc., and with respect to the eight propositions from the psychology of waiting lines according to Maister (1985).

The teacher can ask a group to volunteer to go to the front of the class to share their mapping and action plan with the class. Based on the material presented by this group, the teacher should request contributions and comments from the other groups about what they have done differently and about what they do not agree with suggestions that may complement the plan presented in order to generate an action plan built by the class as a whole.

Having considered that, the class should last at least 2.5 hours. If the sessions are 1.5 hours long, the teacher should divide the content to be worked on during two classes, totaling 3 hours of discussion. In this case, the times could be divided as follows:

Class 1 ( 1.5 hours): 30 minutes for class opening; 45 minutes for discussion in small groups; 15 minutes of closing discussion to clarify questions (How did it go? Were there any questions?) and for instructions on the 
second class where the solutions will be presented by the groups.

Class 2 ( 1.5 hours): 15 minutes to remember the case and main challenges faced by Fabio Antunes; 1 hour and 15 minutes for joint discussion, maintaining the previously suggested dynamics.

\section{Brief theoretical background}

\section{The conceptand importance of capacity management in services}

Capacity management in service organizations has been one of the key challenges faced by managers in this sector. Capacity can be defined as the productive potential of a process and as the number of people a service system can handle within a given time unit (Figueiredo \& Escobar, 2004; Slack, Chambers, Johnston, \& Betts, 2013).

Some features of the service such as simultaneous production and consumption, intangibility, and perishability make it difficult to manage capacity and to correctly scale the volume of resources necessary to provide the system with adequate capacity (Corrêa \& Corrêa, 2011; Figueiredo \& Escobar, 2004). As services cannot be stored, waiting lines can be formed at peak times and in general service companies face a seasonal demand, and with the presence of customers in the service delivery process, this makes capacity management even more difficult.

The variabilities introduced by customers, especially the variability at the arrival and the variability of the request (Frei, 2006), are also complicating the process of capacity management in systems providing services.

All these specificities from the services sector are present and become even greater challenges in a hospital emergency considering the condition in which customers find themselves (weakened by disease, by pain), the variability of the process (each care is unique and developed according to the patient's disease/health condition), and the variability introduced by the customers themselves who are co-producers of the health service.

In general terms, surveys have shown that waiting for a service can negatively affect the customer's assessment: as customers notice the wait time increasing, satisfaction tends to decrease, negatively impacting the company's image (Haksever, Render, Russell, \& Murdick, 2000; Taylor, 1994). In the health sector, waiting can mean death, making the cost of lack of capacity unacceptable in certain circumstances. On the other hand, the manager needs to pay attention to poor use of resources and the cost of maintaining installed capacity to meet peak demand, which means leveling capacity at peak moments may mean idle and prohibitively costly resources while lowering resources may cost the patient's life.

\section{Mechanisms of adjustment between demand and supply in services}

Several are the paths proposed in literature to achieve the balance between supply and demand when providing services. Some of the proposals to manage or influence demand are as follows: reduce or increase prices, use a reservation system, educate customers and inform them about peak periods, offer complementary and non-seasonal services (Bitran \& Mondschein, 1997; Haksever et al., 2000). On the offer side, authors defend using multi-functional employees; part-time workers; increased customer participation in the process; the extension of operating hours; a better planning of the practices, personnel, and tools employed; using mobile or distributed services; using shared equipment; and using technology and information systems to save time (Bitran \& Mondschein, 1997; Slack et al., 2013).

However, for the application of adjustment mechanisms between demand and supply to be successful, it is necessary to fundamentally understand what drives demand such as customer habits or demand behavior (Bitran \& Mondschein, 1997).

\section{Managing the perception of waiting time}

Even with an optimal capacity management and the behavior of the demand properly analyzed, the variability of the process will certainly cause customers to wait at certain times. Managers should therefore use techniques for managing customer perception (Jones \& Peppiatt, 1996; Maister, 1985; Ng, Wirtz, \& Lee, 1999; Taylor, 1994; among others).

In 1985, David Maister proposed the axioms in his "The Psychology of Waiting Lines" and formulated eight propositions on the perceptions and other psychological aspects of individuals waiting in line: (1) When people are occupied during the waiting time, they notice the waiting time less than when they are not occupied (distraction). (2) The wait that takes place before the scheduled time is perceived as being more mild than the one that occurs after or during the process (moment). (3) Anxiety makes the wait seem longer (anxiety). (4) When there is uncertainty as to when the service will be provided, the wait seems 
longer (uncertainty). (5) The unexplained delays seem longer than those in which there are explanations (explanation). (6) Waits perceived as unjust seem longer (fairness/justice). (7) The more valuable the service, the more people will be willing to wait (value). (8) Solitary waiting seems longer than group waiting (waiting alone). These propositions were later complemented by other authors: new or less frequent users perceive a longer wait time (Jones \& Peppiatt, 1996) and discomfort during the wait leads to the perception that the line is longer (Davis $\&$ Heineke, 2004).

Taylor (1994) sought to study the effects of the duration of the waiting time, what the wait is attributed to, and the degree to which time is filled regarding affective reactions (uncertainty and anxiety) while evaluating the wait and the service itself. The survey was carried out with airline passengers in a situation of a flight delay. The results indicated the following conclusions: (a) longer wait times result in lower punctuality evaluations and lower rankings of total performance; (b) the longer the delay, the more uncertainty the customer feels; (c) the greater the customer's uncertainty, the greater the anger; (d) the more the cause of the delay is perceived as being controllable by the service provider, the greater the anger; e) the more the customers perceive their time to be filled during the wait period, the less anger and uncertainty they feel.

\section{Difficulty in successfully implementing the above mechanisms}

The behavior of health service customers, especially in hospital emergency, is a factor that should be taken into account when the intention is to properly manage waiting lines. In some service situations, such as in the case of hospital emergencies and bank branches, there is a capacity to generate a greater demand for the service, which means that to increase capacity may imply increasing demand, especially if this increase in capacity decreases the waiting time imposed on customers. In these cases, increasing capacity may generate even more demand and waits. Therefore, to solve the waiting line problem, managers should focus more on understanding the relationship between waiting time and customer behavior.

It is important to note that habits and traditions, which define customer behavior, can make it difficult to change existing service delivery systems and their standards of use. In addition to behavioral aspects, it cannot be denied that culture influences people's attitude toward waiting lines and, consequently, the success of the actions implemented.

\section{Case analysis}

The analysis will try to follow the preparatory questions presented previously.

a. Is the information submitted to Fabio Antunes enough to improve the management of the hospital's emergency process? What other information would you request?

The information provided in the case is sufficient to propose an action plan, but this is not the only solution and the student is free to think of other paths that need more information not provided in the case. Thus, the teacher should encourage students to reflect freely on the path to be taken to solve the problem of HSF's emergency unit waiting line.

b. With the information provided in the case, make an analysis of the flow of the emergency care process at Hospital São Felipe. Where are the bottlenecks?

The teacher should give the class freedom to think about the actions to be implemented by HSF, while also encouraging the class to reflect on the variability of the process times (also consider maximum and minimum times), the relevance of using mean times due to the great variability (how about using the median?), and reflect on the simplifications that should be made in order to be able to map the process. The teacher should also stress the importance of having the following information: (a) number of patients treated per day and time slots, (b) the processing time at each stage of the process, (c) the number of professionals available to perform each step of the health care service process.

The following analysis should not be used in the discussion of the case since the objective is to leave the students free to think and propose actions. The teacher should take this analysis with him or her and discuss the action plan presented by the students while underscoring important issues to consider or possible paths to take. The idea, therefore, with this material is to assist the teacher in stimulating the reflection by the students and not to indicate a single path for the students. However, depending on the quality of the prior preparation by the students, it is possible that the teacher may need to direct further discussions, and the following analyses may be very useful in this process. 


\section{Analysis proposed with the teacher's} assistance

The following steps may be required to identify the source of the problem:

a. Map the process (process flow): understand the stages of patient care, since arrival until medical care is provided.

b. Check demand and capacity at each stage of the process.

c. Pay attention to the variability of the execution times at each stage of the process.

d. Analyze patient arrival distribution per day and per hour.

In view of the complexity of the process, it is necessary to define the "cross sections" to be made to analyze the process. If the teacher deems necessary, he or she may suggest the following cross sections proposed:

- Break the process down into parts and at first only map 'from arrival to hospital until medical care is provided.'

- Analyze only the part of the health care period, from 8 AM to 10 PM, which covers $88.5 \%$ of the cases treated while the hospital is open, which is 24 hours.

- Choose the most critical case to analyze: Mondays.
Choose the most critical care to analyze: general clinic care.

Map the screening, even knowing that a large part of the patients do not undergo this process. As this is due to a dysfunction caused by the delay in the screening process, and as the intention is for everyone to undergo the screening, it was considered that the best option would be to map the process considering that it took place in all cases and without dysfunctions.

Likewise, although we know that about $5 \%$ of the patients give up and leave before receiving any care, the choice was made to consider that all those arriving at the hospital should be treated since the cause of them giving up was due to the delay in care, a problem that should be solved from the analysis.

We have the information provided in the case and the cross-section premises are as follows: (a) number of patients treated during the four Mondays in April 2017: 1,311; (b) average number of patients treated during each of the four Mondays of April 17: 327.75; (c) number of patients treated between 8 AM and 10 PM: (88.5\%): 55 (290).

The process flow is represented below:

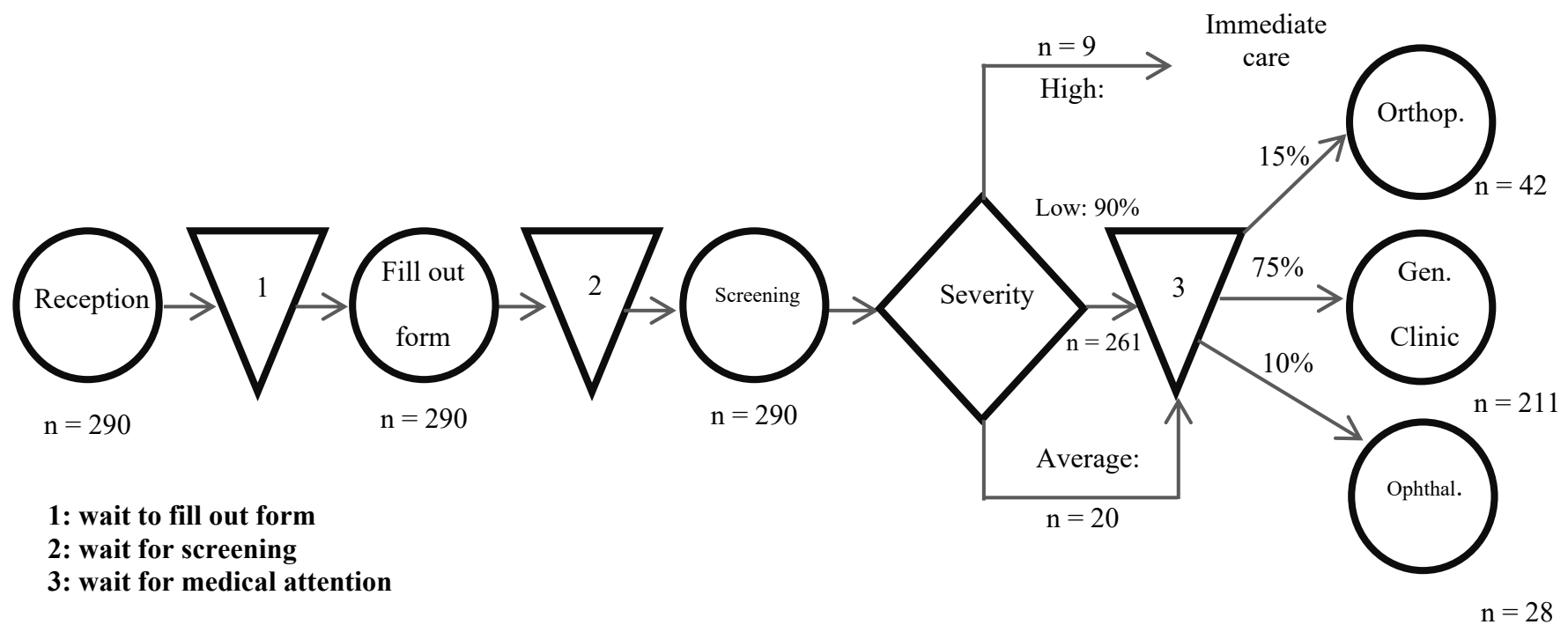

Figure 1. Process flow.

Source: prepared by the authors. 
Table 1 presents the following demand for each stage of the process.

To determine the extent of the problem, it is necessary to define the capacity and compare it with the demand at each stage of the process, and to help with this, Table 2 presents this information, considering the average times in each stage.

Explanation for first column: having two people during the 14 hours that are being analyzed is equivalent to having 28 hours of work available (capacity in hours). Since an average of 4 minutes is required to fill out a form, it is possible to fill out 15 forms per hour, so in 28 hours the system has the capacity to fill out an average of 420 forms. The same reasoning applies to the other columns.

The comparison between demand and capacity is presented in Table 3.

Table 1. Demand at each stage of the process.

\begin{tabular}{|c|c|c|c|c|c|}
\hline $\begin{array}{l}\text { Arrive at emergency } \\
\text { unit } \\
\text { (Reception) }\end{array}$ & $\begin{array}{l}\text { Fill out form at } \\
\text { reception }\end{array}$ & Wait for screening & Go through screening & $\begin{array}{l}\text { Wait for medical care } \\
\text { (from three specialties) }\end{array}$ & $\begin{array}{l}\text { Treated by general } \\
\text { practitioners }(75 \%)\end{array}$ \\
\hline 290 & 290 & 290 & 290 & $\begin{array}{l}281 \text { ( } 3 \% \text { are serious } \\
\text { and go straight to care) }\end{array}$ & 211 \\
\hline
\end{tabular}

Note. Source: prepared by the authors.

Table 2. Capacity at each stage of the process.

\begin{tabular}{|c|c|c|c|}
\hline & Reception & Screening & Medical attention \\
\hline No. of people allocated & 2 & 1 & 2 \\
\hline $\begin{array}{l}\text { Time, from } 8 \text { AM to } 10 \mathrm{PM} \text {, to } \\
\text { perform tasks }\end{array}$ & $28 \mathrm{~h}^{*}=1,680 \mathrm{~min}$ & $11 \mathrm{~h}^{*}=660 \mathrm{~min}$ & $28 \mathrm{~h}^{*} 1,680 \mathrm{~min}$ \\
\hline Average care time (in minutes) & 4 & 5 & 8 \\
\hline No. of patients (capacity) & $15 /$ hour or 420 in period $(15 \times 28)$ & $12 /$ hour or 132 in period $(12 \times 11)$ & $7.5 /$ hour or 210 in period $(28 \times 7.5)$ \\
\hline
\end{tabular}

Note. ${ }^{*}$ During the 14 hours, there are two people available at the reception and two doctors. One person is only available for screening until 7 PM. Source: prepared by the authors.

Table 3. Comparison between capacity and demand at each stage of the process.

\begin{tabular}{|c|c|c|c|}
\hline & Reception & Screening & Medical attention \\
\hline Capacity (No. of patients) & 420 & 132 & 210 \\
\hline Demand & 290 & 290 & 211 \\
\hline Too much or too little capacity & 130 & -158 & -1 \\
\hline
\end{tabular}

Note. Source: prepared by the authors.

Table 3 shows that the bottleneck is at the screening where there is a lack of 14 hours to adequately meet the demand at this stage of the process. It is also important to note that the relocation of employees (from reception, which has too many) to screening is not possible, given the need for specific training to perform screening with patients. One solution perhaps would be to put a doctor to do the screening, especially at peak times, but that decision would probably have some resistance from these professionals. It is also clear that there is an average lack of 7.5 minutes of physicians in the general clinic. This means that on days with less than 290 patients, the care capacity is satisfactory, but on days when the demand is higher than average, the doctors need to see the patients in less time or else the waiting line will get longer and longer. It is also necessary to consider the great dispersion around the average of 8 minutes for each medical treatment. Part of this dispersion is explained by the fact that in $52 \%$ of the doctor visits an exam is requested, the exam is done, and the patient goes back again to be treated by the doctor. This return visit is not accounted for since what the data takes into account is the number of minutes per patient. So a patient can, for example, stay 8 minutes with the physician before he asks for the exam and another 8 after the exam, raising the total care time to 16 minutes. 
It is also important to note the fact that we are analyzing the average treatment times and considering the variability of the process. This may not be the best measure for the central tendency. It would be interesting to also carry out an analysis considering the median and mode of the processing times.
Another factor of extreme importance is the cost of lack of capacity in an emergency hospital, which should be taken into consideration. Because of this, it is necessary to also analyze the process considering its maximum processing times, according to Table 4 below.

Table 4. Comparison between capacity and demand, considering maximum processing times at each stage of the process.

\begin{tabular}{|c|c|c|c|}
\hline & Reception & Screening & Medical attention \\
\hline No. of people allocated & 2 & 1 & 2 \\
\hline $\begin{array}{l}\text { Time, from } 8 \mathrm{AM} \text { to } 10 \mathrm{PM} \text {, to } \\
\text { perform tasks }\end{array}$ & $28 \mathrm{~h}^{*}=1,680 \mathrm{~min}$ & $11 \mathrm{~h}^{*}=660 \mathrm{~min}$ & $28 \mathrm{~h}^{*} 1,680 \mathrm{~min}$ \\
\hline Maximum care time (in minutes) & 21 & 11 & 28 \\
\hline $\begin{array}{l}\text { Processing/hour (forms, patients) in } \\
\text { max. time }\end{array}$ & 3 & 5 & 2.6 \\
\hline $\begin{array}{l}\text { Process capacity (in no. of forms } \\
\text { and patients) }\end{array}$ & 84 & 55 & 73 \\
\hline Demand & 290 & 290 & 211 \\
\hline Too much or too little capacity & -206 & -235 & -138 \\
\hline
\end{tabular}

Note. Source: prepared by the authors.

Considering the maximum processing times as shown on Table 4, capacity would be lacking at all stages of the process, but it is up to the manager to make the following inquiry: Why is there so much variability, for example, in the time for filling out a form, ranging from 1 to 21 minutes? To accept the maximum times in order to minimize the cost from lack of resources could mean incorporating the system's inefficiencies. In other words, the analyses presented in Tables 2 to 4 should be viewed with caution and should be used as an inspiration for seeking information about the reasons for so many variabilities in the process times.

It is also worth mentioning that it is unrealistic to assume that people allocated in all the activities can devote $100 \%$ of their time to the performance expected. At the reception desk, for example, there are frequent interruptions, such as a phone ringing or a person needing some kind of information, that require the employee's attention and ultimately introduce limitations in calculating actual capacity.

c. Develop an action plan addressing aspects related to capacity management, demand management, and dealing with waiting lines. Is the lack of doctors/ nurses or reception staff the main cause of customer dissatisfaction? Explain your answer.

To develop an action plan, it is important to take into account the variability of the demand throughout the hours of the day and during the days of the week. To do so, it is necessary to identify the number of patients arriving every day of the week and by hour. The information presented in Tables A3 and A4 of the case represents the total demand on each day/hour in April 2017. This way, we are going to first analyze what happens to the demand on every day of the week. Starting with Sunday, we know that on the five Sundays of April there were 1,031 people that came to the hospital, reaching an average of 206 patients/Sunday. On the 4 Mondays, 1,311 people came, making the average for Monday to be 328 patients. Repeating this procedure for every day of the week and calculating the weekly average, we get 219. Now we can calculate the index number for each day, which is the representative for each day of the week in relation to the weekly average. Table 5 was built with these values.

Notice, for example, that the index number for Monday is 1.50 , meaning that the demand on Mondays is $50 \%$ higher than the weekly average. The day with the lowest demand is Wednesday, representing $75 \%$ of the weekly average.

The same procedure should be done with the time slots, taking advantage of the data from the Table A4 of this case. The second column of Table 6 , down below, shows that an average of $9.23(286 / 31)$ patients arrived at 8 o'clock in the morning for all the 30 days in April. At 9 o'clock, an average of $14.42(447 / 31)$ patients arrived, and so on. The average arrivals during the 14 hours considered is 13.29 . Now it is possible to build the third column of Table 6 by obtaining the index number associated with each hour slot of the day. 
When the indexes for the day of the week are combined (Table 5) with those for the time slots, the index numbers are obtained per day and per time slot. So, for example, the index number for Sunday is 0.94 and the index number for the range at 8 o'clock in the morning is 0.69. This means that the arrival of patients at $8 \mathrm{AM}$ on Sunday corresponds to the index number $0.94 \times 0.69=$ 0.65 , which means that during this hour slot and on this day, the arrival of patients is $65 \%$ of the weekly average. By extending this calculation for every day and time slot, it can be observed that on Mondays and Tuesdays the demand is higher than the weekly average for almost all time slots. This information is important for managers so that they can distribute the productive resources appropriately depending on the behavior of the demand.

Table 5. Demand per day of the week and index numbers.

\begin{tabular}{lll}
\hline Day of week & Demand per day of the week & Index number \\
\hline Sunday & 206 & 0.94 \\
Monday & 328 & 1.50 \\
Tuesday & 261 & 1.19 \\
Wednesday & 164 & 0.75 \\
Thursday & 181 & 0.83 \\
Friday & 196 & 0.89 \\
Saturday & 196 & 0.89 \\
Average & 219 & 1.00 \\
\hline
\end{tabular}

Note. Source: prepared by the authors.

Table 6. Index numbers by hour time slot and day of week.

\begin{tabular}{|c|c|c|c|c|c|c|c|c|c|}
\hline By hour & $\begin{array}{l}\text { Patients per } \\
\text { hour }\end{array}$ & $\begin{array}{l}\text { Index } \\
\text { number }\end{array}$ & Sunday & Monday & Tuesday & Wednesday & Thursday & Friday & Saturday \\
\hline $8 \mathrm{AM}$ & 9.23 & 0.69 & 0.65 & 1.04 & 0.83 & 0.52 & 0.58 & 0.62 & 0.62 \\
\hline $9 \mathrm{AM}$ & 14.42 & 1.08 & 1.02 & 1.63 & 1.29 & 0.81 & 0.90 & 0.97 & 0.97 \\
\hline $10 \mathrm{AM}$ & 15.77 & 1.19 & 1.12 & 1.78 & 1.41 & 0.89 & 0.99 & 1.06 & 1.06 \\
\hline $11 \mathrm{AM}$ & 16.55 & 1.25 & 1.17 & 1.87 & 1.48 & 0.93 & 1.03 & 1.11 & 1.11 \\
\hline 12 noon & 14.42 & 1.08 & 1.02 & 1.63 & 1.29 & 0.81 & 0.90 & 0.97 & 0.97 \\
\hline $1 \mathrm{PM}$ & 13.29 & 1.00 & 0.94 & 1.50 & 1.19 & 0.75 & 0.83 & 0.89 & 0.89 \\
\hline $2 \mathrm{PM}$ & 14.06 & 1.06 & 0.99 & 1.59 & 1.26 & 0.79 & 0.88 & 0.94 & 0.94 \\
\hline $3 \mathrm{PM}$ & 13.68 & 1.03 & 0.97 & 1.54 & 1.22 & 0.77 & 0.85 & 0.92 & 0.92 \\
\hline $4 \mathrm{PM}$ & 13.48 & 1.01 & 0.95 & 1.52 & 1.21 & 0.76 & 0.84 & 0.90 & 0.90 \\
\hline $5 \mathrm{PM}$ & 12.32 & 0.93 & 0.87 & 1.39 & 1.10 & 0.70 & 0.77 & 0.83 & 0.83 \\
\hline $6 \mathrm{PM}$ & 12.52 & 1.03 & 0.97 & 1.54 & 1.22 & 0.77 & 0.85 & 0.92 & 0.92 \\
\hline 7 PM & 12.90 & 0.97 & 0.91 & 1.46 & 1.16 & 0.73 & 0.81 & 0.86 & 0.86 \\
\hline $8 \mathrm{PM}$ & 12.71 & 0.96 & 0.90 & 1.43 & 1.14 & 0.72 & 0.79 & 0.85 & 0.85 \\
\hline 9 PM & 9.74 & 0.73 & 0.69 & 1.10 & 0.87 & 0.55 & 0.61 & 0.65 & 0.65 \\
\hline $10 \mathrm{PM}$ & 8.32 & 0.63 & 0.59 & 0.94 & 0.75 & 0.47 & 0.52 & 0.56 & 0.56 \\
\hline Average & 13.29 & 1 & 0.94 & 1.50 & 1.19 & 0.75 & 0.83 & 0.89 & 0.89 \\
\hline
\end{tabular}

Note. Source: prepared by the authors.

Now, by comparing the demand for services with the treatment capacity measured by the availability of staff (reception, screening, and doctors), it is possible to verify in which slots per day of the week there is a conflict between capacity and demand, which justify the complaints from the customers. Tables 7,8 , and 9 provide this analysis per day of greatest demand: Monday. 
Table 7. Comparison between demand and capacity in process for filling out form.

\begin{tabular}{|c|c|c|c|c|c|c|c|c|}
\hline \multicolumn{9}{|c|}{ Process: fill out form (average times) } \\
\hline \multicolumn{2}{|l|}{ Monday } & \multicolumn{2}{|l|}{ Demand } & \multicolumn{3}{|l|}{ Capacity } & \multirow[b]{2}{*}{$\begin{array}{l}\text { Too much/too } \\
\text { little in terms } \\
\text { of minutes }\end{array}$} & \multirow[b]{2}{*}{$\begin{array}{l}\text { Too much/too } \\
\text { little in terms } \\
\text { of employees }\end{array}$} \\
\hline Time & $\begin{array}{l}\text { No. patients/ } \\
\text { hour }\end{array}$ & $\begin{array}{l}\text { Average time } \\
\text { to fill out form } \\
\text { (min) }\end{array}$ & $\begin{array}{l}\text { Average time } \\
\text { required for all } \\
\text { forms (min) }\end{array}$ & $\begin{array}{l}\text { No. employees } \\
\text { available }\end{array}$ & $\begin{array}{l}\text { Minutes } \\
\text { available/ } \\
\text { employee }\end{array}$ & $\begin{array}{l}\text { Total minutes } \\
\text { available }\end{array}$ & & \\
\hline $8 \mathrm{AM}$ & 10 & 4 & 39 & 2 & 60 & 120 & 81 & 1,35 \\
\hline $9 \mathrm{AM}$ & 24 & 4 & 94 & 2 & 60 & 120 & 26 & 0,43 \\
\hline $10 \mathrm{AM}$ & 28 & 4 & 113 & 2 & 60 & 120 & 7 & 0,12 \\
\hline $11 \mathrm{AM}$ & 31 & 4 & 124 & 2 & 60 & 120 & -4 & $-0,07$ \\
\hline 12 noon & 24 & 4 & 94 & 2 & 60 & 120 & 26 & 0,43 \\
\hline $1 \mathrm{PM}$ & 20 & 4 & 80 & 2 & 60 & 120 & 40 & 0,67 \\
\hline $2 \mathrm{PM}$ & 22 & 4 & 89 & 2 & 60 & 120 & 31 & 0,52 \\
\hline $3 \mathrm{PM}$ & 21 & 4 & 85 & 2 & 60 & 120 & 35 & 0,58 \\
\hline $4 \mathrm{PM}$ & 21 & 4 & 82 & 2 & 60 & 120 & 38 & 0,63 \\
\hline $5 \mathrm{PM}$ & 17 & 4 & 69 & 2 & 60 & 120 & 51 & 0,85 \\
\hline $6 \mathrm{PM}$ & 19 & 4 & 77 & 2 & 60 & 120 & 43 & 0,72 \\
\hline 7 PM & 19 & 4 & 75 & 2 & 60 & 120 & 45 & 0,75 \\
\hline $8 \mathrm{PM}$ & 18 & 4 & 73 & 2 & 60 & 120 & 47 & 0,78 \\
\hline $9 \mathrm{PM}$ & 11 & 4 & 45 & 2 & 60 & 120 & 75 & 1,25 \\
\hline
\end{tabular}

Nota. Source: prepared by the authors.

At 8 o'clock on Monday, approximately 10 patients are expected (weekly average for that hour slot: 9.23) multiplied by the index number for Mondays at $8 \mathrm{AM}$ (1.04). By calculating the need for assistance at reception in number of minutes and comparing that with the minutes available, it can be seen that one employee in the reception during that time slot would be enough (note that in the column of time required for all the forms, the software used did not take into account possible rounding). When extending the calculation to all time slots, a small staff deficit is seen only at the 11 o'clock slot with enough staff during all others. It is logical that the distribution of arrival is not uniform throughout each hour and that some patients may need more than 4 minutes, but what Table 7 reveals is that if the reception is not able to satisfactorily meet the entire demand (and we analyzed the worst case, Mondays), it is because the staff allocated there are not being properly supervised and/or are performing other activities other than receiving the patients arriving. Another question that arises is if the third attendant spends his or her entire time requesting authorization from the health insurance companies.

Table 8 shows a similar analysis for screening. Here the scenario is quite different. The last column reveals a systematic deficit of at least one more professional for this activity and a third attendant would be needed for the time slots of 10 and 11 o'clock. If Fabio could get the authorization to have at least one more person to do the screening on Mondays and Tuesdays, the problem with this stage would be almost completely resolved.

Finally, Table 9 presents the analysis for the medical care. The numbers in the first column are different from those shown in Tables 7 and 8 because the physicians receive only $75 \%$ of the patients that arrive. The analysis performed considers that two physicians work the waiting line. The case reports that there is a third doctor, the shift supervisor, who divides his time between internal activities and patient care. Therefore, during some hour time slots it is possible to count on a third doctor. Here it is important to remember the limitation related to the dispersion around the average time of patient care by the physician. When the physician requests a laboratory exam or an X-ray, the patient returns to the physician, increasing the care time dedicated to that patient.

The last column of Table 9 shows that on Mondays there is a need for a third doctor during many hour slots. Because of this, the shift supervisor doctor should work with patient care on Mondays, leaving the internal activities for the other days of the week when the calculations are similar to those in Table 9 showing that the two physicians allocated to clinical care are idle during many hours during the day. 
Table 8. Comparison between demand and capacity in screening process.

\begin{tabular}{|c|c|c|c|c|c|c|c|c|}
\hline \multicolumn{9}{|c|}{ Process: screening (average times) } \\
\hline \multicolumn{2}{|l|}{ Monday } & \multicolumn{2}{|l|}{ Demand } & \multicolumn{3}{|l|}{ Capacity } & \multirow[b]{2}{*}{$\begin{array}{l}\text { Too much/too } \\
\text { little in terms } \\
\text { of minutes }\end{array}$} & \multirow[b]{2}{*}{$\begin{array}{l}\text { Too much/too } \\
\text { little in terms } \\
\text { of employees }\end{array}$} \\
\hline Time & $\begin{array}{l}\text { No. patients/ } \\
\text { hour }\end{array}$ & $\begin{array}{l}\text { Average time } \\
\text { for screening } \\
\text { (min) }\end{array}$ & $\begin{array}{l}\text { Time needed } \\
\text { for all } \\
\text { screenings } \\
(\mathrm{min})\end{array}$ & $\begin{array}{l}\text { No. of } \\
\text { employees } \\
\text { available }\end{array}$ & $\begin{array}{l}\text { Minutes } \\
\text { available / } \\
\text { employee }\end{array}$ & $\begin{array}{l}\text { Total minutes } \\
\text { available }\end{array}$ & & \\
\hline $8 \mathrm{AM}$ & 10 & 5 & 48 & 1 & 60 & 60 & 12 & 0.20 \\
\hline $9 \mathrm{AM}$ & 24 & 5 & 118 & 1 & 60 & 60 & -58 & -0.97 \\
\hline $10 \mathrm{AM}$ & 28 & 5 & 141 & 1 & 60 & 60 & -81 & -1.35 \\
\hline $11 \mathrm{AM}$ & 31 & 5 & 155 & 1 & 60 & 60 & -95 & -1.58 \\
\hline 12 noon & 24 & 5 & 118 & 1 & 60 & 60 & -58 & -0.97 \\
\hline $1 \mathrm{PM}$ & 20 & 5 & 100 & 1 & 60 & 60 & -40 & -0.67 \\
\hline $2 \mathrm{PM}$ & 22 & 5 & 112 & 1 & 60 & 60 & -52 & -0.87 \\
\hline $3 \mathrm{PM}$ & 21 & 5 & 106 & 1 & 60 & 60 & -46 & -0.77 \\
\hline $4 \mathrm{PM}$ & 21 & 5 & 103 & 1 & 60 & 60 & -43 & -0.72 \\
\hline $5 \mathrm{PM}$ & 17 & 5 & 86 & 1 & 60 & 60 & -26 & -0.43 \\
\hline $6 \mathrm{PM}$ & 19 & 5 & 96 & 1 & 60 & 60 & -36 & -0.60 \\
\hline 7 PM & 19 & 5 & 94 & 0 & 60 & 0 & -94 & -1.57 \\
\hline $8 \mathrm{PM}$ & 18 & 5 & 91 & 0 & 60 & 0 & -91 & -1.52 \\
\hline $9 \mathrm{PM}$ & 11 & 5 & 57 & 0 & 60 & 0 & -57 & -0.95 \\
\hline
\end{tabular}

Note. Source: prepared by the authors.

Table 9. Comparison between demand and capacity in the clinical care process.

\begin{tabular}{|c|c|c|c|c|c|c|c|c|}
\hline \multicolumn{9}{|c|}{ Process: medical care (average times) } \\
\hline \multicolumn{2}{|c|}{ Monday } & \multicolumn{2}{|l|}{ Demand } & \multicolumn{3}{|l|}{ Capacity } & \multirow[b]{2}{*}{$\begin{array}{l}\text { Too much/too } \\
\text { little in terms } \\
\text { of minutes }\end{array}$} & \multirow[b]{2}{*}{$\begin{array}{l}\text { Too much/too } \\
\text { little in no. of } \\
\text { doctors }\end{array}$} \\
\hline Time & $\begin{array}{l}\text { No. of patients } \\
\text { treated }\end{array}$ & $\begin{array}{l}\text { Average care } \\
\text { time }\end{array}$ & $\begin{array}{l}\text { Time needed } \\
\text { to provide care } \\
\text { (min) }\end{array}$ & $\begin{array}{l}\text { No. of doctors } \\
\text { available }\end{array}$ & $\begin{array}{l}\text { Minutes } \\
\text { available/ } \\
\text { doctor }\end{array}$ & $\begin{array}{l}\text { Total of } \\
\text { minutes } \\
\text { available }\end{array}$ & & \\
\hline $8 \mathrm{AM}$ & 7 & 8 & 58 & 2 & 60 & 120 & 62 & 1.03 \\
\hline $9 \mathrm{AM}$ & 18 & 8 & 142 & 2 & 60 & 120 & -22 & -0.37 \\
\hline $10 \mathrm{AM}$ & 21 & 8 & 169 & 2 & 60 & 120 & -49 & -0.82 \\
\hline $11 \mathrm{AM}$ & 23 & 8 & 186 & 2 & 60 & 120 & -66 & -1.10 \\
\hline 12 noon & 18 & 8 & 142 & 2 & 60 & 120 & -22 & -0.37 \\
\hline $1 \mathrm{PM}$ & 15 & 8 & 120 & 2 & 60 & 120 & 0 & 0.00 \\
\hline $2 \mathrm{PM}$ & 17 & 8 & 134 & 2 & 60 & 120 & -14 & -0.23 \\
\hline $3 \mathrm{PM}$ & 16 & 8 & 127 & 2 & 60 & 120 & -7 & -0.12 \\
\hline $4 \mathrm{PM}$ & 15 & 8 & 123 & 2 & 60 & 120 & -3 & -0.05 \\
\hline $5 \mathrm{PM}$ & 13 & 8 & 103 & 2 & 60 & 120 & 17 & 0.28 \\
\hline $6 \mathrm{PM}$ & 14 & 8 & 116 & 2 & 60 & 120 & 4 & 0.07 \\
\hline 7 PM & 14 & 8 & 113 & 1 & 60 & 60 & -53 & -0.88 \\
\hline $8 \mathrm{PM}$ & 14 & 8 & 110 & 1 & 60 & 60 & -50 & -0.83 \\
\hline $9 \mathrm{PM}$ & 8 & 8 & 64 & 1 & 60 & 60 & -4 & -0.07 \\
\hline
\end{tabular}

Note. Source: prepared by the authors. 
The following action plan can be proposed according to the quantitative analyses:

\section{Capacity management:}

Screening seems to be the largest bottleneck in the process. The placement of one more person to do screening would already be enough to reduce the waiting times and minimize all the resulting problems. The more people in the waiting room for longer periods, the greater will be the observations of situations experienced by patients, potentially increasing and spreading dissatisfaction. The complaint about the behavior of the front desk attendants is an example. The analysis shows that the number of receptionists is usually higher than necessary. Why do they leave their job post so often?

It is worth remembering that the analyses were performed considering average times, but it is important to notice the variabilities of the process. Though the attempt was to detail the demand by day of the week and by hour time slots, there are limitations on the assumption that the arrival of patients is uniform during each hour.

Technology - the automation of some processes would certainly bring benefits to the hospital since, according to customer accounts (Appendix 4), the process is very dependent on paper and people.

In short, with the data used in the analysis, there are few moments during the week when it can be said that there is a lack of installed capacity. The problem seems to be in the inadequate use of this capacity, causing a lot of time waste and complaints from customers, and rightly so. The fragmentation of the process and the communication failures between employees become clear with the complaints presented in Figure A1. Supervising activities and controlling how staff consumes working time may be more important than redefining the system's capacity.

\section{REFERENCES}

Bitran, G., \& Mondschein, S. (1997). Managing the tug-of-war between supply and demand in the service industries. European Management Journal, 15(5), 523-536. https://doi.org/10.1016/S0263-2373(97)00032-7

Corrêa, H. L., \& Corrêa, C. A. (2011). Administração da produção e operaçôes: Manufatura e serviços - uma abordagem estratégica (2nd ed.). São Paulo: Atlas.

Davis, M., \& Heineke, J. (2004). Operations management: Integrating manufacturing and services (5th ed.). Boston: McGraw-Hill.

\section{Demand management:}

Educate the patient about what an emergency is and inform them about the emergency services offered by the hospital. Informative/educational videos could be shown on the TV in the waiting room, which is currently connected to an open channel, generating dissatisfaction among those who are waiting. One of these educational videos could give a subtle message that days such as Mondays and Tuesdays should be avoided by those who do not need to come in on those more congested days. The hospital tries to assist everyone, even if they are not emergency cases, but it should communicate this to the customers asking for their understanding for waiting. The problem seems to be the conditions of waiting.

3. Managing the wait and the psychology of waiting lines:

The letter received by Fabio Antunes, as well as the complaints expressed in Figure A1, makes it clear that several simple actions can and should be taken for better managing the perception of the waiting time by customers: reduce how cold it is in the waiting room; solve the problem of the door creaking (uncomfortable waiting seems longer); reconsider the information panel, which seems to be generating anxiety (anxiety increases the perception of waiting time); inform the customer about the waiting time (unknown waiting seems longer); inform the customer about the patient care criteria (unfair waiting seems longer); occupy the customer during the wait with informative videos about the hospital and its emergency (unoccupied time seems longer); importance of an efficient screening and agility in working the waiting line so that the customer feels in the process of being monitored (pre-process waiting seems longer); review the reception layout because the patients are always coming back to the same location they were in before, giving the feeling that they are not evolving in the process. It is obvious that you could propose building new waiting rooms during the process to avoid these trips of going back and forth, giving the impression of the patient being a 'product in-process,' but certainly space constraints prevent these new rooms from becoming possible.

Figueiredo, K., \& Escobar, D. (2004). Gestão de capacidade em serviços. Relatório COPPEAD, (360).

Frei, F. X. (2006). Breaking the trade-off between efficiency and service. Harvard Business Review, 84(11), 92-101. Retrieved from https://hbr.org/2006/11/breaking-thetrade-off-between-efficiency-and-service

Haksever, C., Render, B., Russell, R.S., \& Murdick, R. G. (2000). Service management and operations. Upper Saddle River, NJ: Prentice Hall. 
Jones, P., \& Peppiatt, E. (1996). Managing perceptions of waiting times in service queues. International Journal of Service Industry Management, 7(5), 47-61. https://doi.org/10.1108/09564239610149957

Maister, D. (1985). The psychology of waiting lines. In J. A. Czepiel, M. R. Solomon, C. F. Surprenant (Eds.), The service encounter: Managing employeelcustomer interaction in service businesses. Lexington, MA: Lexington Books.

\section{Authorship}

\section{Claudia Affonso Silva Araujo*}

Universidade Federal do Rio de Janeiro, Instituto COPPEAD de Administração

Rua Pascoal Lemme, no 355, Cidade Universitária, 21941-918, Rio de Janeiro, RJ, Brazil.

Fundação Getulio Vargas, Escola de Administraçáo de Empresas de São Paulo

Av. Nove de Julho, no 2029, $2^{\circ}$ andar, Bela Vista, 01313-902 , São Paulo, SP, Brazil.

E-mail address: claraujo@coppead.ufrj.br

(1) https://orcid.org/0000-0003-0290-4807

\section{Kleber Fossatti Figueiredo}

Universidade Federal do Rio de Janeiro, Instituto COPPEAD de Administração

Rua Pascoal Lemme, no 355, Cidade Universitária, 21941-918, Rio de Janeiro, RJ, Brazil.

E-mail address: kleber@coppead.ufrj.br

(1) https://orcid.org/0000-0003-4498-231X

* Corresponding Author

\section{Funding}

There are no funders to report for this article.
Ng, I., Wirtz, J., \& Lee, K. (1999). The strategic role of unused service capacity. International Journal of Service Industry Management, 10(2), 211-244. https://doi.org/10.1108/09564239910264352

Slack, N., Chambers, S., Johnston, R., \& Betts, A. (2013). Gerenciamento de operaçóes e de processos (2nd ed.). Porto Alegre: Bookman.

Taylor, S. (1994). Waiting for service: The relationship between delays and evaluations of service. Journal of Marketing, 58(2), 5669. https://doi.org/10.1177\%2F002224299405800205

\section{Authors' Contributions}

$1^{\text {st }}$ author: conceptualization (lead); data curation (lead); formal analysis (equal); investigation (lead); methodology (supporting); writing-original draft (lead).

$2^{\text {nd }}$ author: conceptualization (supporting); data curation (supporting); formal analysis (equal); methodology (lead); writing-original draft (supporting).

\section{Conflict of Interests}

The authors have stated that there is no conflict of interest.

\section{Copyrights}

RAC owns the copyright to this content.

\section{Plagiarism Check}

The RAC maintains the practice of submitting all documents approved for publication to the plagiarism check, using specific tools, e.g.: iThenticate.

\section{Peer Review Method}

This content was evaluated using the double-blind peer review process. The disclosure of the reviewers' information on the first page, as well as the Peer Review Report, is made only after concluding the evaluation process, and with the voluntary consent of the respective reviewers and authors. 